knowledge reliably. Among their works, Violetta de Angelis' essay on Lucan should be singled out both as an example of outstanding scholarship and as the one among them that is able to make some conclusive points and get very close to important breakthroughs, particularly concerning Cato and his placement in Purgatory. Hollander's catalogue - which, although considered preliminary by the author, already represents a greatly improved tool for Dante scholars - should also be distinguished from the other works just mentioned, in that it deals with internal facts of the text rather than with its historical context.

While the papers fall generally into two categories, the interpretive and the philological, the most recurrent theme in the first group, that Dante's echoes of his sources contain a built-in commentary, can, as lannucci points out, be linked directly to the premise of the other papers, that the medieval reader would not be accustomed to reading the classical poets in isolation from various forms of commentary. All of the articles contained in this collection are valid contributions to the study of Dante and the classical tradition and the volume itself is all the more welcome for having presented them together as, among other things, a convincing illustration of their relevance to each other despite the variety of their authors' scholarly origins.

\title{
MARGUERITE CHIARENZA
}

The University of British Columbia

Deborah Parker. Commentary and Ideology: Dante in the Renaissance. Durham, N.C.: Duke UP, 1993. Pp. 248.

"This book is an attempt to reclaim an interpretive legacy" (159). The legacy to which Deborah Parker refers in this summary statement of intent is the "extrinsic" approach, the historicist rather than the hermeneutic mode of interpretation. The author is urging the righting of what she sees as a present imbalance in critical studies, by refocusing on the legacy of Dante commentary: on ideological and social issues, and on literary reception and material production. To continue reading the Comedy "in the relative isolation of most current editions, thereby shearing it from its successive interpretations and reinterpretations," Parker wams, "is to read in practical ignorance" (158). This book is at once both an appeal for a reorientation of critical methodology - one which may require that we "read more, work collaboratively, publish less, and offer more tenuous conclusions" (160) - and a demonstration of the value of this mode of interpretation.

To demonstrate that the recognition of ideological and political concerns rests at the center of an understanding of the reception of Dante's poem, Chapters 3, 4, and 5 focus on commentary as a form of mediation between the Comedy and particular social agendas. This mediation is shaped by the role of institutions (Chapters 3 and 4 ) and by particular conceptions of imitation and authorship (Chapter 5). Chapter 6 demonstrates how an examination of the material production of the Comedy in the Renaissance can be applied to the resolving of current problems of Dante scholarship.

The critical debate which developed in the Renaissance over the dramatization of Brutus and Cassius in Inferno 34.61-67 forms the nucleus of a demonstration in Chapter 3 of how the Comedy both defined and was in turn redefined by culture, as commentary became a political tool for the legitimization of power groups. Parker perceives such an 
episode as a "litmus test" not only of the commentator but also of the culture that informs him (58). From Benvenuto da Imola (the first commentator to challenge Dante's presentation), to the response of Trifone Gabriele to Cristoforo Landino (the most influential commentator in the Renaissance), this chapter follows the vicissitudes of sympathy for and against Brutus and Cassius. In so doing it demonstrates how ideological commitments necessitate particular hermeneutic strategies, how interpretative content is shaped by influences both within and outside of the commentary tradition. This demonstration also reveals the limitations of the utility of this methodology, since "the paucity of information" on the lives of two commentators subsequent to Landino - Alessandro Vellutello and Bernardino Daniello - "renders their treatment of the Brutus and Cassius episode less readable" (87).

Chapter 4, in focusing on Gabriele's sustained critique of Landino, illustrates the importance of the social and cultural position of these commentators, and underlines the failure of "an idealistic textual tradition" that depends solely on "the comparison of texts" to recognize the differences which inform their critiques (97). Since the publication of Landino's commentary, for example, was part of a Medici agenda for the promotion of the city of Florence and its language, Landino (who depended on the Medici for his candidacy for the chair of rhetoric and poetry in the Florentine Studio) was faced with such problems as how to deal with the coarseness of Dante's language, and with the poet's denunciations of the city. Gabriele, on the other hand, living in relative freedom from political obligation and institutional ties, was free to comment as a detached intellectual. And finally, while Landino's commentary was to dominate Dante studies for more than a century, Gabriele's reputation, which was linked to his unpublished annotations, faded soon after his death. This enormous difference in the fate of their work can only be explained by giving attention "to the role of institutions in shaping critical tradition and critical evaluation" (108).

Since the necessary documentation to carry out an analysis of the role of institutions in the formation of commentary is not always available, Chapter 5 explores what Parker terms a requisite "kind of critical bricolage" (109). The focus for this exploration is the commentary of Bernardino Daniello. First of all, the proper assessment of the nature of Daniello's debt to Trifone Gabriele requires an understanding of the conventional sixteenth-century attitude toward authorship and imitation. Such an understanding makes it possible to "judge Daniello's commentary in a way that it has never been judged - on its own terms rather than on the more modern terms critics have brought to it." Viewed in this light, Daniello's "massive incorporation of his teacher's ideas" becomes "an act of conservation, not theft" (111). Secondly, the lukewarm reception of Daniello's commentary requires an examination of sociohistorical features influencing its production. It is necessary to look at the contrast between the particulars of the material production of Daniello's commentary and of Landino's; to look at Daniello's detachment from controversy and polemic as compared to Landino's distinctive expression of his own cultural moment.

The relationship between interpretation and the material production of the Comedy begins in Chapter 6 with a review of the work published in this field to date. All the studies examined "assume an oppositional stance toward traditional bibliographic procedures and emphasize the importance of examining a work's production, reproduction, and reception" (130). The remainder of this chapter examines the significance of format, type, illustrations, and the inclusion or exclusion of commentary, as both influencing and being influenced by reader's response. The introduction of the editor, especially in the 
case of Aldus Manutius, was of great import in the history of the reception of Dante's poem, as was the publication of the first French editions, which entailed particular glossing for a new audience. This chapter ends with a consideration of the question of the poem's title, as a means of demonstrating the relevance of material production in resolving current problems of scholarship. Since the initial reception of the Comedy lacks crucial evidence, it becomes necessary to reverse the traditional privileging of originary moments over the history of productivity.

The above examinations are prefaced by two introductory chapters, the first dealing with the scholarly reception of Dante criticism in the nineteenth and twentieth centuries, the second with the reception and manipulation of medieval commentary by Renaissance commentators. The momentum created by positivism, nationalism and antiquarianism drives forward the movement from commentary to criticism of commentary in the nineteenth century. This momentum continues into the twentieth century with the publication of and studies on the background of early commentaries, aided by philological activity and the study of medieval poetics. Most recent work, in Parker's opinion, "has focused on ... what the text, considered from a formal standpoint means" (20). She recommends the theories of Mikhail Bakhtin and Hans Robert Jauss for the needed task of taking a closer look at the issues of reception and influence, for finding "a way of gauging the social force and ultimately the meaning of these different registers of speech" (21).

Beginning with a brief discussion of the methodology of Dante's auto exegesis, Chapter 2 charts the changing agenda of commentary in its first two centuries. By the turn of the fourteenth century the defensive prospectus of the earliest commentators had given way to changing "horizons of expectations" (35). The focus shifted from a need for legitimizing the authority of Dante's text against his detractors to a need for convincing a different culture of the Comedy's enduring relevance. Dante's authority having been established, commentary took on the task of negotiating the relationship between the poem and the specific expectations of a particular audience. The nature of this negotiation is demonstrated in the remainder of this chapter by following the ways in which modifications in the most prominent features of Trecento commentary were brought about through the pressure of historical change in the Renaissance. In the closing section of this chapter, entitled "Toward a Dynamic Theory of Commentary," Parker calls for a change in the present tendency to ignore the dominance of digression as a significant feature of medieval criticism: "What is needed now is a conception of commentary that allows for heterogeneity ... a theory and a critical vocabulary that illuminates discontinuity in these texts and is sensitive to the essentially dialogic nature of the medieval text." Heteroglossia (as conceived by Bakhtin), results from the fact that "commentary at its most basic level is a consideration of the Comedy as a social act" (46). With humanism comes the need to redirect the meaning of Dante's poem. What had been perceived as a repository of doctrine comes to be interpreted as a rhetorical performance. Just as Dante reinterpreted his own work according to shifting religious and philosophical needs, so humanists reinterpreted meaning to conform to contemporary social and political demands.

This study is rounded out by very extensive, richly detailed and exhaustively researched notes. At a time when the major Dante commentaries are becoming accessible to us in an unprecedented manner through the medium of the Dartmouth Dante Project, it is fitting that we should be made aware of the need for a serious reorientation of study to address the sociohistorical significances of these works. Historical context, Parker warns, is easily occluded by the power of such a project. "The introduction of this new set of 
material conditions for the study of commentary," therefore, "must be accompanied by a critical self-consciousness" (23).

CAROLYNN LUND-MEAD

University of Toronto

Paul Colilli. La poetica dell' aletheia nell' "Africa" del Petrarca. Rovito (CS): Marra, 1993. Pp. 106.

In the preface of La poetica dell' aletheia, Paul Colilli describes in Heideggerian terms Petrarch's contribution to humanist thinking as a return to pre-Socratic principles: "L'apporto principale del Petrarca (assieme ad altre figure del primo Umanesimo) allo sviluppo del pensiero umanistico consiste proprio nella riscoperta del concetto presocratico secondo il quale la parola poetica è dotata di capacità cognitive oltre ad essere con la teologia l'unico tramite che permetta all'uomo di approdare ad un 'autentica scoperta delle sue origini divine" (9). Colilli divides his examination of the aletheian poetics of the Africa into three "phases," corresponding to the three chapters of the book (9). The first chapter ("Petrarca, Heidegger e l'aletheia poetologica") seeks to establish the similarity of the thinking of Petrarch and Heidegger through their common rejection of Scholasticism. Instead, Colilli contends, the poet and philosopher insist on the distinction between Being and beings and reveal the significance of Being and truth through the metaphors of veiling and un-veiling. The second chapter ("L'aletheia filologica") presents various revisions to the Palace of Truth episode of book three of the Africa and posits them as constituting "uno spazio ermeneutico tutto particolare" $(10,54)$ through which the discussion can turn to the "nulla che è inciso nel discorso aletheiologico" (54). Finally, after an appendix containing the revisions, the third chapter ("Attraverso il nulla [l'ascesa di Scipione al Campidoglio]") focuses on the figure of Scipio as a transient through the abyss of nothingness. This last chapter hinges on the connection between writing and nothingness and uses the ascent of Scipio in the ninth book of the poem to show how the previous books (especially books three through eight) conversely represent a descent into the abyss of nothingness. Colilli concludes by designating the poetizing thought ("il pensiero poetante") of Petrarch as post-Medieval, explaining that: "Il «post» di post-medievo è la differenza, ovvero non il «dopo» della «rottura» bensì l'«adesso» della differenza. Il Rinasc; mento è il «dopo». Il «post» è più un momento di vuoto, di nulla" (88). Colilli thus preserves a unique position for Petrarch as the first humanist poet.

Emesto Grassi's Renaissance Humanism serves as the point of departure for La poetica dell' aletheia, although Colilli generally seems to misunderstand Grassi's argument. Colilli cites Grassi's opinion that Heidegger and the Italian humanists share "l'idea che il pensiero poetante è l'elemento che conduce l'uomo dall'oscurità dell'oblio alla luce della coscienza storica e della civiltà" (12) but then takes issue with Grassi's view that Petrarch offers an unsuccessful defense of poetry. Colilli painstakingly quotes and paraphrases, almost line for line, the four pages dealing with Petrarch at the end of the first chapter of Grassi's book. He concludes his summary with the same two questions with which Grassi ends his chapter, namely: "Is it the function of the logical or the metaphori- 